\title{
A 15 C's Pathway of Sustainability in Environmental Health Management \& The Crucial Role of Higher Education Institutions
}

\author{
Sotirios Maipas ${ }^{1}$
}

\begin{abstract}
Manmade environmental degradation has created an unsustainable status quo posing many known and yet unknown environmental health threats. Innovation, which may be considered as a function of time, location, and explicit and tacit knowledge acquisition, is essential for the effective and sustainable management of environmental health issues. The following series of C's may function as a pathway towards sustainability in environmental health management: (1) Consciousness of the urgency, (2) Comprehension of the complexity, (3) Confidence in our ability to change, (4) Capacitybuilding for decision-making, (5) Cooperation among stakeholders, (6) Carbon footprint reduction, (7) Circular economy adoption, (8) Corporate sustainability, (9) Creativity (Creative thinking and action), (10) Creation of resilient and adaptive communities, (11) Creation of sustainable living environments for all social groups, (12) Creation of new explicit and tacit knowledge, (13) Communication of the new knowledge, (14) Curriculum updates, and (15) Crisis management. Apart from the emerging teaching and research priorities, the proposed pathway requires a strategic higher education institutions' contribution to the necessary societal transformation towards sustainability. Higher education institutions could play a crucial role in all the described steps of this 15 C's pathway and in the interconnections between them. Each step may offer emerging opportunities for innovative planning and action towards a more sustainable future. However, further research and pilot applications are necessary for the evaluation of the proposed theoretical model.
\end{abstract}

Keywords: Education, Environmental health, Innovation, Sustainability, Tacit knowledge

\footnotetext{
${ }^{1}$ Physicist MSc, PhD, MBA Cd, Research Associate at Master Program "Environment and Health. Management of Environmental Health Effects", School of Medicine, National and Kapodistrian University of Athens, Greece, e-mail: sotgmaip@gmail.com
} 


\section{Introduction}

From the time of ancient cisterns and aqueducts and of the first suburban dump constructed outside ancient Athens, up until the potential future use of plastic-eating microorganisms, humanity is constantly striving to meet environmental health (EH) innovation milestones (Mays, 2014; Yang et al., 2015; Avgerinou et al., 2016; Koren, 2017). Despite this constant innovation in the EH sector, innovation differs vastly from one geographical area to another; this difference is especially visible between the developed and developing world (van Nieuwenhuijzen et al., 2009; Luzi et al., 2016; Zanello et al., 2016; Lausselet et al., 2017). The capacity for innovation differs not only among countries, but also among various institutions, between the public and private sector, and between firms of different sizes within a certain country (Nieto \& Santamaría, 2010; Wang \& Wang, 2012; Bloch \& Bugge, 2013). It is obvious that innovation - which is essential for the effective and sustainable management of EH issues (Metz et al., 2016; Karjalainen et al., 2017; Demir et al., 2019) - can be considered as a function of time, location, and explicit and tacit knowledge acquisition.

Environmental degradation has created an unsustainable status quo that poses several known and unknown threats to EH (Costello et al., 2009; Smith et al., 2014; Kim \& Zoh, 2016; Carratt et al., 2017; IPCC, 2019; Makris, 2019). Humans' relationships with their natural and man-made environments are multi-dimensional and are governed by socio-economic, cultural, health, ethical, and religious aspects (Schulz \& Northridge, 2004; Costello et al., 2009; Morrison et al., 2015; Udofia et al., 2015; Fatorić et al., 2017; Weir et al., 2017; Tol, 2018; IPCC, 2019). All stakeholders have to act urgently and cooperate closely to deal with these threats, such as changing weather and landscape patterns, impacts on agriculture and the economy, food - and water-insecurity issues, increasing healthcare costs, and negative impacts on cultural heritage - such as archaeological sites (Costello et al., 2009; Daly, 2014; Zahid et al., 2015; Rojas-Downing et al., 2017; Tol, 2018; IPCC, 2019; Makris, 2019). A joint, innovative, interdisciplinary, and interprofessional effort among higher education institutions (HEIs), authorities, energy providers, the entire private and public sector, and local people is urgently required to mitigate and reverse the increasing deterioration of EH (Mapira \& Mazambara, 2013; Eta \& Angba, 2017; Howarth \& Monasterolo, 2017; Mason et al., 2017; Milman et al., 2017; Klein et al., 2018; Tang \& Demeritt, 2018; Elsner et al., 2019; IPCC, 2019; Makate et al., 2019; Makris, 2019). Given the nature of environmental problems, humanity must also adopt intergenerational cooperation (between current and future generations) to ensure sustainability.

Important factors affecting $\mathrm{EH}$ are legislation, the proper management of scientific uncertainty, and the management and transfer of relevant explicit and tacit knowledge (Cavusgil et al., 2003; Sen, 2005; Huang \& Shih, 2009; Lwoga, 2010; Hens \& Stoyanov, 2014; Iacobuta et al., 
2018; Makondo \& Thomas, 2018; Reis \& Spencer, 2019). Moreover, the tacit and traditional knowledge of local indigenous communities, combined with scientific and technological advances, could generate innovations capable of speeding up sustainability (Tripathi \& Bhattarya, 2004; Hunter, 2005; Nyong et al., 2007; Santha, 2010; Chhetri et al., 2012; Makondo \& Thomas, 2018; Oroma \& Guma, 2018; Makate et al., 2019).

The aim of this paper is to propose a pathway of sustainability in EH management, and to highlight the significant role HEIs could play in this process. The key aspects of EH will also be briefly covered.

\section{A 15 C's Pathway of Sustainability in EH Management}

$\mathrm{EH}$ is defined as the facet of public health concerned with the natural and man-made environmental factors that have the potential to impact health (McSwane et al., 2015; Frumkin, 2016). Several different professionals are involved in EH, including doctors, physicists, social and political scientists, civil engineers, architects, psychologists, zoologists, and food and noise inspectors (Fitzpatrick, 2002). One of the most common examples of an EH issue is climate change (CC). CC affects human health both directly (though extreme weather events) and indirectly (for example, through airborne and vector-borne diseases). It is considered to be the most significant global health threat of this century (Costello et al., 2009; Smith et al., 2014; IPCC, 2019).

Environmental crises are unavoidable and require appropriate management (Wisner \& Adams, 2003; Moser \& Luers, 2008; de Bruijn et al., 2017; IPCC, 2019). Moreover, vulnerable groups, including low-income families, people with medical conditions, and homeless people must be protected immediately (Costello et al., 2009; Akerlof et al., 2015). 
The following series of "C's" could be a pathway towards sustainability in EH management:

\begin{tabular}{l}
\hline Consciousness of the urgency \\
$\downarrow$ \\
\hline Comprehension of the complexity \\
$\downarrow$ \\
\hline Confidence in our ability to change \\
$\downarrow$ \\
\hline Capacity-building for decision-making \\
$\downarrow$ \\
\hline Cooperation among stakeholders \\
$\downarrow$ \\
\hline Carbon footprint reduction \\
$\downarrow$ \\
\hline Circular economy adoption \\
$\downarrow$ \\
\hline Corporate sustainability \\
$\downarrow$ \\
\hline Creativity \\
\hline$\downarrow$ \\
\hline Creative thinking and action) \\
\hline Curriculum updates \\
$\downarrow$ \\
\hline Creation of resilient and adaptive \\
communities \\
$\downarrow$ \\
\hline Creation of new explicit and tacit knowledge \\
\hline Creation of sustainable living environments \\
for all social groups \\
\hline \\
\hline Communication of the new knowledge \\
\hline
\end{tabular}

Figure 1: 15C's Pathway in EH Management 
HEIs and firms are among the most important agents in this pathway. Both can promote innovation by investing in human capital and research, and by adopting sustainable strategies (Cortese, 2003; Benn et al., 2006; Smith et al., 2011; Amini \& Bienstock, 2014; Perić \& Delić, 2016; Boiral \& Heras-Saizarbitoria, 2017; Skanavis et al., 2017; Geissdoerfer et al., 2018; Michalena, 2018; Olopade et al., 2020). Research could serve as an innovative driver of sustainability, including the proposal of newer methods and technologies that emit fewer greenhouse gases or reduce packaging waste (Benn et al., 2006; Fernández Fernández et al., 2018; Clark et al., 2019). Research is also necessary to understand the complexity of $\mathrm{EH}$ issues, eliminate environmental injustice, and reduce scientific uncertainty (Kundzewicz et al., 2018; Schreckenberg, 2018).

\section{The crucial role of HEIs}

Each educational institution is a complex system, which comprises students and teaching staff, buildings and indoor environments, and various services. Further, educational institutions have their own carbon footprint, and should lead by example by reducing it (Alajmi et al., 2012; Lambrechts \&Van Liedekerke, 2014; Berchin et al., 2018). These institutions must promote research and prepare students to become responsible citizens and future decision-makers (Cortese, 2003; Mitchell \& Weiler, 2011; Maxwell \& Blashki, 2016; Perić \& Delić, 2016; Eta \& Angba, 2017; Skanavis et al., 2017; Berchin et al., 2018). Therefore, it is imperative that they invest in relevant research, disseminate knowledge, establish lifelong learning networks, and participate in the shaping of proper mitigation strategies against CC and other EH threats (Mohd Ghazali et al., 2007; Ardalan et al., 2013; Azeiteiro et al., 2015; Skanavis et al., 2017). HEIs must become important agents of the change, working towards sustainability (Cortese, 2003; Ćulum et al., 2013; Foo, 2013; Zamora-Polo \& Sánchez-Mertín, 2019). Their proper interaction and cooperation with all stakeholders—such as the government, firms, non-governmental organizations, and local communities - is crucial (Henstra, 2017; Galvao et al., 2009; Pundt \& Heilmann, 2020).

Education for sustainable development must cover factors associated with EH by introducing new courses, constantly updating existing ones, and by organizing relevant lifelong learning programs (Khalaf-Kairouz, 2012; Azeiteiro et al., 2015; Obasi \& Ogwuche, 2016; Ahonen \& Lacey, 2017; Lasker et al., 2019). The curricula of the many disciplines related to EH, such as agriculture, economics, social sciences, psychology, law, and management sciences (see Fitzpatrick, 2002), must constantly evolve not only to cover the market needs (Tavoletti, 2010), but also to ensure sustainability (Khalaf-Kairouz, 2012). 
Education for sustainable development must also include indigenous knowledge transmission (Kaya \& Seleti, 2013; Ford et al., 2014). This important type of knowledge must be recorded, stored in databases, properly incorporated into curricula, and disseminated adequately (Hunter, 2005; Sen, 2005; Mapira \& Mazambara, 2013; Ford et al., 2014; Makondo \& Thomas, 2018; Oroma \& Guma, 2018). Further, formal strategies against environmental degradation should integrate indigenous knowledge in favor of sustainability, such as in the case of CC (Nyong et al., 2007). HEIs should act as depositaries and guardians of indigenous and traditional knowledge and skills.

\section{Conclusion}

Todays' economies are unfortunately expanding in an unsustainable manner, increasing the burden on the environment. However, humanity now has the knowledge, skills, and technology to turn the current unsustainable status quo into a reality where current and future generations can thrive. Given the fact that higher education's traditional missions of teaching and research are not enough for achieving sustainability, educational institutions must adopt a more strategic role that transforms them into socially responsible "gates" to a sustainable future. Regarding EH, a joint, innovative, and effective effort among HEIs, authorities, the private and public sector, and local people is urgently required to mitigate and reverse the constant deterioration of EH.

This paper suggests a theoretical framework towards sustainability in the EH-management field. HEIs could play a crucial role in all the described steps and in the interconnections between them. Further research and pilot applications are necessary for the evaluation of the proposed theoretical model. 


\section{References}

Ahonen, E.Q., \& Lacey, S.E. (2017). Undergraduate Environmental Public Health Education: Developmental Evaluation to Reframe a Degree in a New School. NEW SOLUTIONS: A Journal of Environmental and Occupational Health Policy, Vol. 27, No 1, pp. 107-123.

Akerlof, K.L., Delamater, P.L., Boules, C.R., Upperman, C.R., \& Mitchell, C.S. (2015). Vulnerable Populations Perceive Their Health as at Risk from Climate Change. International Journal of Environmental Research and Public Health, Vol. 12, No 12, pp. 15419-15433.

Alajmi, A. (2012). Energy audit of an educational building in a hot summer climate. Energy and Buildings, Vol. 47, pp. 122-130.

Amini, M., \& Bienstock, C.C. (2014). Corporate sustainability: an integrative definition and framework to evaluate corporate practice and guide academic research. Journal of Cleaner Production, Vol. 76, pp. 12-19.

Ardalan, A., Mesdaghinia, A., Masoumi, G., Naieni, K. H., \& Ahmadnezhad, E. (2013). Higher Education Initiatives for Disaster and Emergency Health in Iran. Iranian Journal of Public Health, Vol. 42, No 6, pp. 635-638.

Avgerinou, P., Chiotis, E.D., Chrysoulaki, S., Defteraios, P., Evangelou, T., Gigourtakis, N.M., Kakes, G., Kourtzellis, Y., Koutis, P., Mamassis, N., Pappa, M., Peppas, G. \& Strataridaki, A.I. (2016). Updated Appraisal of Ancient Underground Aqueducts in Greece. In A.N. Angelakis, E. Chiotis, S. Eslamian, H. Weingartner (Eds.), Underground Aqueducts Handbook (pp. 4362). Boca Raton, London, New York: CRC Press.

Azeiteiro, U.M., Bacelar-Nicolau, P., Caetano, F.J., \& Caeiro, S. (2015). Education for sustainable development through e-learning in higher education: experiences from Portugal. Journal of Cleaner Production, Vol. 106, pp. 308-319.

Benn, S., Dunphy, D., \& Griffiths, A. (2006). Enabling Change for Corporate Sustainability: An Integrated Perspective. Australasian Journal of Environmental Management, Vol. 13, No 3, pp. $156-165$

Berchin, I.I., da Silva, S.A., Ceci, F., Gabriel, G.M., Anhalt, T.C., \& Guerra, J. B. (2018). The Role of Universities to Promote Sustainable Practices and Climate Change Adaptation: Analysis of the 22 Conferences of the Parties Using Text Mining. In W. Leal Filho, F. Frankenberge, P. Iglecias, R.C. Kronka Mülfarth (Eds.), Towards Green Campus Operations (pp. 251-278). Cham, Switzerland: Springer. 
Bloch, C., \& Bugge, M.M. (2013). Public sector innovation-From theory to measurement. Structural Change and Economic Dynamics, Vol. 27, pp. 133-145.

Boiral, O., \& Heras-Saizarbitoria, I. (2017). Best practices for corporate commitment to biodiversity: An organizing framework from GRI reports. Environmental Science \& Policy, Vol. 77, pp. 7785.

Carratt, S.A., Flayer, C.H., Kossack, M.E., \& Last, J.A. (2017). Pesticides, wildfire suppression chemicals, and California wildfires: A human health perspective. Current Topics in Toxicology, Vol. 13, pp. 1-12.

Cavusgil, S.T., Calantone, R.J., \& Zhao, Y. (2003). Tacit knowledge transfer and firm innovation capability. Journal of Business \& Industrial Marketing, Vol. 18, No 1, pp. 6-21.

Chhetri, N., Chaudhary, P., Tiwari, P.R., \& Yadaw, R.B. (2012). Institutional and technological innovation: Understanding agricultural adaptation to climate change in Nepal. Applied Geography, Vol. 33, pp. 142-150.

Clark, N., Trimingham, R.L., \& Wilson, G.T. (2019). Understanding consumer disposal behaviour with food to go packaging in a move to circular, zero waste packaging solutions. Paper presented at the Third PLATE Conference, Berlin, Germany, 18-20 September 2019. Retrieved from

https://repository.lboro.ac.uk/articles/Understanding_consumer_disposal_behaviour_with_food to_go_packaging_in_a_move_to_circular_zero_waste_packaging_solutions/9352646

(Accessed on 05 February 2020).

Cortese, A.D. (2003). The Critical Role of Higher Education in Creating a Sustainable Future. Planning for Higher Education, Vol. 31, No 3, pp. 15-22.

Costello, A., Abbas, M., Allen, A., Ball, S., Bell, S., Bellamy, R., Friel, S., Groce, N., Johnson, A., Kett, M., Lee, M., Levy, C., Maslin, M., McCoy, D., McGuire, B., Montgomery, H., Napier, D., Pagel, C., Patel, J., Antonio J., de Oliveira, P., Redclift, N., Rees, H., Rogger, D., Scott, J., Stephenson, J., Twigg, J., Wolff, J., Patterson, C. (2009). Managing the health effects of climate change. The Lancet, Vol. 373, No 9676, pp. 1693-1733.

Ćulum, B., Rončević, N., \& Ledić, J. (2013). Facing new expectations-Integrating third mission activities into the university. In B. M. Kehm, U. Teichler (Eds.), The Academic Profession in Europe: New Tasks and New Challenges (pp. 163-195). Springer. 
Daly, C. (2014). A Framework for Assessing the Vulnerability of Archaeological Sites to Climate Change: Theory, Development, and Application. Conservation and Management of Archaeological Sites, Vol. 16, No 3, pp. 268-282. de Bruijn, K., Buurman, J., Mens, M., Dahm, R., \& Klijn, F. (2017). Resilience in practice: Five principles to enable societies to cope with extreme weather events. Environmental Science \& Policy, Vol. 70, pp. 21-30.

Demir, C., Cergibozan, R., \& Ari, A. (2019). Environmental dimension of innovation: time series evidence from Turkey. Environment, Development and Sustainability, doi: 10.1007/s10668018-00305-0.

Elsner, I., Monstadt, J., \& Raven, R. (2019). Decarbonising Rotterdam? Energy transitions and the alignment of urban and infrastructural temporalities. City, Vol. 23, No 4-5, pp. 646-657.

Eta, H.C., \& Angba, A.O. (2017). Climate Change Adaptation in Yam and Cassava Production, Cross River State, Nigeria: The Role of Higher Educational Institutions. In W. Leal Filho (Ed.), Climate Change Research at Universities (pp. 275-289). Springer, Cham, Switzerland: Springer.

Fatorić, S., \& Seekamp, E. (2017). Are cultural heritage and resources threatened by climate change? A systematic literature review. Climatic Change, Vol. 142, No 1-2, pp. 227-254.

Fernández Fernández, Y., Fernández López, M.A., \& Olmedillas Blanco, B. (2018). Innovation for sustainability: the impact of $\mathrm{R} \& \mathrm{D}$ spending on $\mathrm{CO}_{2}$ emissions. Journal of Cleaner Production, Vol. 172, pp. 3459-3467.

Fitzpatrick, M. (2002). Environmental Health Services in Europe 6: The development of professional associations. Copenhagen: World Health Organization.

Foo, K.Y. (2013). A vision on the role of environmental higher education contributing to the sustainable development in Malaysia. Journal of Cleaner Production, Vol. 61, pp. 6-12.

Ford, P.L., Prior, J., Coat, B., \& Warton, L. (2014). The Incorporating Indigenous Knowledge LibGuide: Charles Darwin University Embedding Australian Aboriginal and Torres Strait Islander Knowledge, Culture and Language. Australian Academic \& Research Libraries, Vol. 45, No 2, pp. 111-120.

Frumkin, H. (2016). Environmental Health: From Global to Local. San Francisco: John Wiley \& Sons. 
Galvao, A., Mascarenhas, C., Marques, C., Ferreira, J., \& Ratten, V. (2019). Triple helix and its evolution: a systematic literature review. Journal of Science and Technology Policy Management, Vol. 10, No 3, pp. 812-833.

Geissdoerfer, M., Morioka, S.N., de Carvalho, M.M., \& Evans, S. (2018). Business models and supply chains for the circular economy. Journal of Cleaner Production, Vol. 190, 712-721.

Hens, L., \& Stoyanov, S. (2014). Education for climate changes, environmental health and environmental justice. Journal of Chemical Technology \& Metallurgy, Vol. 49, No 2, pp. 194208.

Henstra, D. (2017). Climate adaptation in Canada: Governing a Complex Policy Regime. Review of Policy Research, Vol. 34, No 3, pp. 378-399.

Howarth, C., \& Monasterolo, I. (2017). Opportunities for knowledge co-production across the energy-food-water nexus: Making interdisciplinary approaches work for better climate decision making. Environmental Science \& Policy, Vol. 75, pp. 103-110.

Huang, P.S., \& Shih, L.H. (2009). Effective environmental management through environmental knowledge management. International Journal of Environmental Science \& Technology, Vol. 6, No 1, pp. 35-50.

Hunter, J. (2005). The Role of Information Technologies in Indigenous Knowledge Management. Australian Academic \& Research Libraries, Vol. 36, No 2, pp. 109-124.

Iacobuta, G., Dubash, N.K., Upadhyaya, P., Deribe, M., \& Höhne, N. (2018). National climate change mitigation legislation, strategy and targets: a global update. Climate Policy, Vol. 18, No 9, pp. 1114-1132.

IPCC (2019). Summary for Policymakers. In P.R. Shukla, J. Skea, E. Calvo Buendia, V. MassonDelmotte, H.O. Pörtner, D.C. Roberts, P. Zhai, R. Slade, S. Connors, R. van Diemen, M. Ferrat, E. Haughey, S. Luz, S. Neogi, M. Pathak, J. Petzold, J. Portugal Pereira, P. Vyas, E. Huntley, K. Kissick, M. Belkacemi, J. Malley (Eds.), Climate Change and Land: an IPCC special report on climate change, desertification, land degradation, sustainable land management, food security, and greenhouse gas fluxes in terrestrial ecosystems. In Press.

Karjalainen, T., Hoeveler, A., \& Draghia-Akli, R. (2017). European Union research in support of environment and health: Building scientific evidence base for policy. Environment International, Vol. 103, pp. 51-60. 
Kaya, H.O., \& Seleti, Y.N. (2013). African indigenous knowledge systems and relevance of higher education in South Africa. International Education Journal: Comparative Perspectives, Vol. 12, No 1, pp. 30-44.

Khalaf-Kairouz, L. (2012). Education for Sustainable Development at Notre Dame UniversityLouaize: Environmental Science Curriculum-a Pre-Phase to the Rucas Project on Education for Sustainable Development. Discourse and Communication for Sustainable Education, Vol. 3, pp. 121-134.

Kim, M.K., \& Zoh, K.D. (2016). Occurrence and removals of micropollutants in water environment. Environmental Engineering Research, Vol. 21, No 4, pp. 319-332.

Klein, J., Araos, M., Karimo, A., Heikkinen, M., Ylä-Anttila, T., \& Juhola, S. (2018). The role of the private sector and citizens in urban climate change adaptation: Evidence from a global assessment of large cities. Global Environmental Change, Vol. 53, pp. 127-136.

Koren, H. (2017). Best Practices for Environmental Health: Environmental Pollution, Protection, Quality and Sustainability. Routledge.

Kundzewicz, Z.W., Krysanova, V., Benestad, R.E., Hov, Ø., Piniewski, M., \& Otto, I.M. (2018). Uncertainty in climate change impacts on water resources. Environmental Science \& Policy, Vol. 79, pp. 1-8.

Lambrechts, W., \& Van Liedekerke, L. (2014). Using ecological footprint analysis in higher education: Campus operations, policy development and educational purposes. Ecological Indicators, Vol. 45, pp. 402-406.

Lasker, G.A., Mellor, K.E., \& Simcox, N.J. (2019). Green chemistry \& chemical stewardship certificate program: a novel, interdisciplinary approach to green chemistry and environmental health education. Green Chemistry Letters and Reviews, Vol. 12, No 2, pp. 178-186.

Lausselet, C., Cherubini, F., Oreggioni, G.D., del Alamo Serrano, G., Becidan, M., Hu, X., Rørstad P.K, \& Strømman, A.H. (2017). Norwegian Waste-to-Energy: Climate change, circular economy and carbon capture and storage. Resources, Conservation and Recycling, Vol. 126, pp. 50-61.

Luzi, S., Tobler, M., Suter, F., Meierhofer, R. (2016). SODIS manual: Guidance on solar water disinfection. Dübendorf, Switzerland: Sandec, Eawag. Retrieved from: https://www.sodis.ch/methode/anwendung/ausbildungsmaterial/dokumente_material/sodisman ual_2016.pdf (Accessed on 4 February 2020). 
Lwoga, E.T., Ngulube, P., \& Stilwell, C. (2010). Managing indigenous knowledge for sustainable agricultural development in developing countries: Knowledge management approaches in the social context. The International Information \& Library Review, Vol. 42, No 3, pp. 174-185.

Makate, C., Makate, M., Mango, N., \& Siziba, S. (2019). Increasing resilience of smallholder farmers to climate change through multiple adoption of proven climate-smart agriculture innovations. Lessons from Southern Africa. Journal of Environmental Management, Vol. 231, pp. 858-868.

Makondo, C.C., \& Thomas, D.S. (2018). Climate change adaptation: Linking indigenous knowledge with western science for effective adaptation. Environmental Science \& Policy, Vol. 88, pp. 8391.

Makris, K.C. (2019). Drinking Water and Human Health Challenges in the Twenty-First Century. In P. Maurice (Ed.), Encyclopedia of Water. doi: 10.1002/9781119300762.wsts0162.

Mapira, J., \& Mazambara, P. (2013). Indigenous knowledge systems and their implications for sustainable development in Zimbabwe. Journal of Sustainable Development in Africa, Vol. 15, No 5, pp. 90-106.

Mason, C.F., Polasky, S., \& Tarui, N. (2017). Cooperation on climate-change mitigation. European Economic Review, Vol. 99, pp. 43-55.

Maxwell, J., \& Blashki, G. (2016). Teaching About Climate Change in Medical Education: An Opportunity. Journal of Public Health Research, Vol. 5. doi: 10.4081/jphr.2016.673.

Mays, L.W. (2014). Use of cisterns during antiquity in the Mediterranean region for water resources sustainability. Water Science \& Technology: Water Supply, Vol. 14, No 1, pp. 38-47.

McSwane, D., French, J., Klein, R. (2015). Environmental Health and Safety. In J. Bradsher, G. Wojtala, C. Kaml, C. Weiss, D. Read (Eds.), Regulatory Foundations for the Food Protection Professional (pp. 125-141). New York: Springer.

Metz, P., Burek, S., Hultgren, T.R., Kogan, S., \& Schwartz, L. (2016). The Path to SustainabilityDriven Innovation: Environmental sustainability can be the foundation for increasing competitive advantage and the basis for effective innovation. Research-Technology Management, Vol. 59, No 3, pp. 50-61.

Michalena, E. (2017). Building Green Growth and Entrepreneurship in the Pacific Through Knowledge and Innovation. In S. Sindakis, P. Theodorou (Eds.), Global Opportunities for Entrepreneurial Growth: Coopetition and Knowledge Dynamics within and across Firms (pp. 475-506). Emerald Publishing Limited. 
Milman, A., Marston, J.M., Godsey, S.E., Bolson, J., Jones, H.P., \& Weiler, C.S. (2017). Scholarly motivations to conduct interdisciplinary climate change research. Journal of Environmental Studies and Sciences, Vol. 7, No 2, pp. 239-250.

Mitchell, R.B., \& Weiler, C.S. (2011). Developing next-generation climate change scholars: the DISCCRS experience. Journal of Environmental Studies and Sciences, Vol. 1, No 1, pp. 54-62. Mohd Ghazali, M., Nor Azirawani, M., Norfaryanti, K., \& Mar Idawati, M. (2007). The Application of Knowledge Management in Enhancing the Performance of Malaysian Universities. Electronic Journal of Knowledge Management, Vol. 5, No 3, pp. 301-312.

Morrison, M., Duncan, R., \& Parton, K. (2015). Religion does matter for climate change attitudes and behavior. PloS ONE, Vol. 10, No 8, doi: 10.1371/journal.pone.0134868.

Moser, S.C., \& Luers, A.L. (2008). Managing climate risks in California: the need to engage resource managers for successful adaptation to change. Climatic Change, Vol. 87, No 1, pp. 309-322.

Nieto, M.J., \& Santamaría, L. (2010). Technological collaboration: Bridging the innovation gap between small and large firms. Journal of Small Business Management, Vol. 48, No 1, pp. 4469.

Nyong, A., Adesina, F., \& Elasha, B.O. (2007). The value of indigenous knowledge in climate change mitigation and adaptation strategies in the African Sahel. Mitigation and Adaptation Strategies for Global Change, Vol 12, No 5, v787-797.

Obasi, M.T., \& Ogwuche, J.A. (2016). Environmental Management Education for Sustainable Development in Nigeria. Pyrex Journal of Ecology and the Natural Environment, Vol. 2, No 2, pp. 7-12.

Olopade, B.C., Okodua, H., Oladosun, M., Matthew, O., Urhie, E., Osabohien, R., Aderiran, O., \& Johnson, O.H. (2020). Economic Growth, Energy Consumption and Human Capital Formation: Implication for Knowledge-based Economy. International Journal of Energy Economics and Policy, Vol. 10, No 1, pp. 37-43.

Oroma, J.O., \& Guma, A. (2018). Examining the Use of Information Systems to Preserve Indigenous Knowledge in Uganda: A Case from Muni University. I.J. Modern Education and Computer Science, Vol. 5, pp. 36-43.

Perić, J., \& Delić, A. (2016). Developing social responsibility in Croatian Universities: a benchmarking approach and an overview of current situation. International Review on Public and Nonprofit Marketing, Vol. 13, No 1, v69-80. 
Pundt H., Heilmann A. (2020) Building Collaborative Partnerships: An Example of a 3rd Mission Activity in the Field of Local Climate Change Adaptation. In W. Leal Filho, A. Lange Salvia, R.W. Pretorius, L. Londero Brandli, E. Manolas, F. Alves, U. Azeiteiro, J. Rogers, C. Shiel, A. Do Paco (Eds.), Universities as Living Labs for Sustainable Development (pp.621-636). Cham, Switzerland: Springer.

Reis, J., \& Spencer, P.S. (2019). Decision-making under uncertainty in environmental health policy: new approaches. Environmental Health and Preventive Medicine, Vol. 24, doi: 10.1186/s12199-019-0813-9.

Rojas-Downing, M.M., Nejadhashemi, A.P., Harrigan, T., \& Woznicki, S.A. (2017). Climate change and livestock: Impacts, adaptation, and mitigation. Climate Risk Management, Vol. 16, pp. 145-163.

Santha, S.D., Fraunholz, B., \& Unnithan, C. (2010). A Societal Knowledge Management System: Harnessing Indigenous Wisdom to Build Sustainable Predictors for Adaptation to Climate Change. The International Journal of Climate Change: Impacts and Responses, Vol. 2, No 1, pp. 49-64.

Schreckenberg, D. (2018). Knowledge gaps concerning health impacts of environmental noise. Paper presented at the Euronoise 2018 Congress, Hersonissos, Crete, Greece, 27-31 May 2018. Retrieved from: http://www.euronoise2018.eu/docs/papers/169_euronoise2018.pdf (Accessed on 05 February 2020).

Schulz, A., \& Northridge, M.E. (2004). Social Determinants of Health: Implications for Environmental Health Promotion. Health Education \& Behavior, Vol. 31. No 4, pp. 455-471.

Sen, B. (2005). Indigenous knowledge for development: Bringing research and practice together. The International Information \& Library Review, Vol. 37, No 4, pp. 375-382.

Skanavis, C., Kounani, A., \& Ntountounakis, I. (2017). Greek universities addressing the issue of climate change. In W. Leal Filho (Ed.), Climate Change Research at Universities (pp. 333344). Cham, Switzerland: Springer.

Smith, A., Courvisanos, J., Tuck, J. (2011). Building innovation capacity: the role of human capital formation in enterprises - a review of the literature. Commonwealth of Australia. Retrieved from https://files.eric.ed.gov/fulltext/ED517803.pdf (Accessed on 05 February 2020).

Smith, K.R., Woodward, A., Campbell-Lendrum, D., Chadee, D. D., Honda, Y., Liu, Q., Olwoch, J. M., Revich, B., Sauerborn, R. (2014). Human health: impacts, adaptation, and co-benefits. In C.B. Field, V.R. Barros, D.J. Dokken, K.J. Mach, M.D. Mastrandrea, T.E. Bilir, M. Chatterjee, K.L. Ebi, Y.O. Estrada, R.C. Genova, B. Girma, E.S. Kissel, A.N. Levy, S. MacCracken, P.R. 
Mastrandrea, \& L.L. White (Eds.), Climate Change 2014: Impacts, Adaptation, and Vulnerability. Part A: Global and Sectoral Aspects. Contribution of Working Group II to the Fifth Assessment Report of the Intergovernmental Panel on Climate Change (pp. 709-754). Cambridge University Press.

Tang, S., \& Demeritt, D. (2018). Climate Change and Mandatory Carbon Reporting: Impacts on Business Process and Performance. Business Strategy and the Environment, Vol. 27, No 4, pp. 437-455.

Tavoletti, E. (2010). Matching Higher Education with the Labour Market in the Knowledge Economy: The Much-Needed Reform of University Governance in Italy. Industry and Higher Education, Vol. 24, No 5, pp. 361-375.

Tol, R. S. (2018). The Economic Impacts of Climate Change. Review of Environmental Economics and Policy, Vol. 12, No 1, pp. 4-25.

Tripathi, N., \& Bhattarya, S. (2004). Integrating Indigenous Knowledge and GIS for Participatory Natural Resource Management: State-of-the-Practice. The Electronic Journal of Information Systems in Developing Countries, Vol. 17, No 1, pp. 1-13.

Udofia, E.I., Wilcox, R.I., \& Akadi, A.P. (2015). Climate change issues and implications for sustainable development in a coastal area of Nigeria. World Scientific News, Vol. 24, pp. 43-55. van Nieuwenhuijzen, A.F., Havekes, M., Reitsma, B.A., \& De Jong, P. (2009). Wastewater treatment plant Amsterdam West: new, large, high-tech and sustainable. Water Practice and Technology, Vol. 4, No 1, doi: 10.2166/wpt.2009.006.

Wang, Z., \& Wang, N. (2012). Knowledge sharing, innovation and firm performance. Expert Systems with Applications, Vol. 39, No 10, pp. 8899-8908.

Weir, T., Dovey, L., \& Orcherton, D. (2017). Social and cultural issues raised by climate change in Pacific Island countries: an overview. Regional Environmental Change, Vol. 17, No 4, pp. 1017-1028.

Wisner, N., Adams, J. (2003). Environmental Health in Emergencies and Disasters. Malta, Italy: World Health Organization.

Yang, Y., Yang, J., Wu, W. M., Zhao, J., Song, Y., Gao, L., Yang, R., \& Jiang, L. (2015). Biodegradation and mineralization of polystyrene by plastic-eating mealworms: Part 1 . Chemical and physical characterization and isotopic tests. Environmental Science \& Technology, Vol. 49, No 20, pp. 12080-12086.

Zahid, A.T., Khan, F.A., \& Bhat, S.A. (2015). Health Care Cost and Climate Change: Confronting the Strategical Challenges. International Journal of Multidisciplinary Approach \& Studies, Vol. 2, No 6, pp. 82-92. 
Zamora-Polo, F., \& Sánchez-Martín, J. (2019). Teaching for a Better World. Sustainability and Sustainable Development Goals in the Construction of a Change-Maker University. Sustainability, Vol. 11, No 15, p. 4224.

Zanello, G., Fu, X., Mohnen, P., \& Ventresca, M. (2016). The creation and diffusion of innovation in developing countries: A systematic literature review. Journal of Economic Surveys, Vol. 30, No 5, pp. 884-912. 